\title{
BILATERAL AND REGIONAL ASPECTS OF AZERBAIJAN-KAZAKHSTAN RELATIONS
}

\author{
Halit HAMZAOĞLU ${ }^{1}$
}

\begin{abstract}
Azerbaijan and Kazakhstan are two independent countries that share a common history, traditions, and cultural ties. After independence, both countries have achieved significant political and economic successes. The amicable relations between the two countries were strengthened with the "Amicable relations and strategic partnership declaration between the Republic of Azerbaijan and the Republic of Kazakhstan" signed in Nur-Sultan on 1 March 2004. With the "Agreement on strategic partnership and alliance relations between the Republic of Azerbaijan and the Republic of Kazakhstan" signed in Baku on May 24, 2005, the relationship have reached a strategic level. The economic relations and joint projects between the two countries play an important role in ensuring regional stability and prosperity. A common history, traditions, and cultural ties allow the further expansion and development of the strategic relations between Azerbaijan and Kazakhstan.
\end{abstract}

Keywords: Azerbaijan, Common projects, Cooperation mechanisms, Kazakhstan, Regional politics

JEL Codes: F50, F53, F59

\section{İKILİ VE BÖLGESEL YÖNLERIYLE AZERBAYCAN-KAZAKISTAN İLISŞKILERİ}

\section{$\ddot{O} \mathbf{z}$}

Azerbaycan ve Kazakistan ortak tarihi, gelenekleri ve kültürel bağları paylaşan iki bağımsız ülkedir. Bağımsızlık sonrası her iki ülke hem siyasi hem de ekonomik anlamda önemli başarılar kazanmışlardır. İki ülke arasında yakın dostluk ilişkileri, 1 Mart 2004'te Nur-Sultan'da imzalanan “Azerbaycan Cumhuriyeti ve Kazakistan Cumhuriyeti arasındaki dostluk ilişkileri ve Stratejik Ortaklık Deklarasyonu” ile güçlendirilmiştir. 24 Mayıs 2005'te Bakü'de imzalanan "Azerbaycan Cumhuriyeti ile Kazakistan Cumhuriyeti arasında stratejik ortaklık ve müttefiklik ilişkileri Antlaşması" ile ilişkiler stratejik düzeye ulaşmıştır. İki ülke arasında var olan ekonomik ilişkiler ve ortak projeler, bölgesel istikrarın ve refahın sağlanmasında önemli rol oynamaktadır. Ortak tarih, gelenekler ve kültürel bağlar Azerbaycan- Kazakistan stratejik ilişkilerinin daha da genişlemesine ve gelişmesine olanak tanımaktadır. Anahtar Kelimeler: Azerbaycan, Bölgesel politikalar, İşbirliği mekanizmaları, Kazakistan, Ortak projeler JEL Kodları: F50, F53, F59

\footnotetext{
${ }^{1}$ Dr. Öğr. Üyesi, Kafkas Üniversitesi, halithamzaoglu85@gmail.com, ORCID 0000-0001-5249-1911.

Başvuru Tarihi (Received): 04.05.2021 Kabul Tarihi (Accepted): 25.10.2021
} 


\section{Introduction}

Common historical and cultural ties bring together Azerbaijan and Kazakhstan, which gained their independence with the dissolution of the Union of Soviet Socialist Republics (USSR). Political, economic, and cultural relations between these two countries, which are the shining stars of the Turkic World, are critical in terms of ensuring regional stability and prosperity. Mutual trust in bilateral relations is supported by multi-dimensional cooperation mechanisms. The two countries cooperate constructively in international and regional institutions such as the United Nations (UN), Turkic Council, Commonwealth of Independent States (CIS), Economic Cooperation Organization (ECO), and International Organization of Turkic Culture (TURKSOY).

The basic research question of our study is the assumption that constructive relations and cooperation between Azerbaijan and Kazakhstan are of key importance for regional stability and prosperity. In this study, the analysis of bilateral political relations, joint economic activities and cultural ties is evaluated based on this assumption. In this context, the importance of cooperation in the fields of energy and transportation is emphasized, and the role of cultural ties in the further expansion of cooperation is explored. However, it is underlined that rational interests also direct the development of relations between the two countries. In the study, it is emphasized that these interests and cultural ties enable Azerbaijan-Kazakhstan relations to reach the level of strategic partnership.

The study consists of three main titles and subsections that allows for better understanding of each main title. The first part of the study focuses on the development of political relations between Azerbaijan and Kazakhstan and the importance and functionality of mutual visits in bilateral relations are emphasized. This section mentions the importance of the cooperation between the two countries in determining the legal status of the Caspian Sea. Moreover, the attitude of Kazakhstan in the context of the Nagorno-Karabakh problem is investigated.

In the second part, the economic relations that exist between Azerbaijan and Kazakhstan are analyzed from the perspective of cooperation in the fields of energy and transportation. It is emphasized that the economic cooperation between the two countries contributes to the stability and prosperity in the Caucasus, Central Asia and Caspian regions.

\section{Bilateral Political Relations}

Diplomatic relations between Azerbaijan and Kazakhstan were established on 30 August 1992. On January 9, 1993, the Embassy of the Republic of Kazakhstan in Azerbaijan began its activities. On March 1, 2004, the Embassy of the Republic of Azerbaijan in Kazakhstan became operational (Heydar Aliyev Heritage, 2010). Bilateral relations have developed within the framework of good neighborliness, mutually beneficial cooperation mechanisms, and close or similar positions on international and regional issues (Sultanov,2009). Since the Soviet period there have been fraternal ties between the two countries at the level of political, economic, and cultural relations (Muhamedjanov, 2009: 7). After independence, these ties have deepened and the relations between the two countries have acheieved a strategic level.

After Heydar Aliyev came to power in Azerbaijan in 1993, he started to pursue a balanced foreign policy strategy. In this context, relations with Kazakhstan were especially important in terms of providing political support regarding the Nagorno-Karabakh conflict and economic projects (Huseynov, 2017: 140). The development of bilateral relations has been reinforced by mutual visits of the presidents. Azerbaijani leader Heydar Aliyev (1993-2003) visited Almaty after his official visit to China on March 2, 1994, and met with Kazakhstan leader Nursultan Nazarbayev. In the meeting held in a friendly atmosphere, diverse areas of cooperation between the two countries were discussed. In this context, it was emphasized that there were great opportunities to strengthen cooperation (Ahmedov, 2013). 
The meeting between Azerbaijani President Heydar Aliyev and Kazakhstan President Nursultan Nazarbayev at the Turkic States Summit held in Istanbul on October 19, 1994, was a turning point for the development of bilateral relations. During the meeting, the perspective of the development of relations between the two countries was discussed, and it was decided Azerbaijan-Kazakhstan relations be established both within the framework of relations between Turkic states and at the bilateral level (Heydar Aliyev Heritage, 2010).

On February 29, 1995, President Heydar Aliyev attended the CIS Presidents' Summit held in Kazakhstan. With this visit of Heydar Aliyev, a new stage in bilateral relations was initiated. Aliyev met with Kazakhstan leader Nazarbayev within the scope of the visit and issues related to bilateral relations were discussed. Cooperation in diplomatic, political, energy, economic, cultural, and humanitarian fields was the main focus of the negotiations (Huseynova, 2014). Developing bilateral and multilateral relations within the scope of these areas was the main priority for both countries.

On 9-10 August 1995, Heydar Aliyev participated in the $150^{\text {th }}$ Commemoration Ceremony of the great Kazakh poet Abai Kunanbayev organized by the United Nations Educational Scientific and Cultural Organization (UNESCO) in Almaty (Ahmedov, 2013). In his meeting with President Nazarbayev, Aliyev emphasized that the economic relations between the two countries should be further developed and he also touched on the problem of the common use of the Caspian Sea. At the end of the meeting, Aliyev invited the leader of Kazakhstan to Azerbaijan for an official visit (Huseynova, 2014).

Based on the aforementioned invitation, President Nazarbayev paid an official visit to Baku on 1617 September 1996. During the visit, for the first time, the content of political, economic, and cultural relations was discussed concretely, and thus, the foundations of the formation of amicable relations were laid (Ahmedov, 2013). During the visit, an important agreement "On the Basics of Relations between the Republic of Azerbaijan and the Republic of Kazakhstan" was signed (Heydar Aliyev Heritage, 2010).In addition, cooperation agreements were signed between the parties on the fields of promotion and protection of investments, the oil and gas industry, and air transport (Heydar Aliyev Heritage,2010). A joint declaration was announced on the Caspian problem, which is one of the regional-scale issues. One of the remarkable issues addressed during the visit was the development of institutional cooperation between the two countries. The documents signed between the parties during Nazarbayev's visit to Baku brought along new historical opportunities for the development of relations (Ahmedov,2013). Thus, the visit prepared suitable groundwork for the development and expansion of multilateral cooperation between Azerbaijan and Kazakhstan.

During the Fourth Summit of the Head of Turkic Speaking Countries in October 1996, talks were held between Aliyev and Nazarbayev. Nazarbayev invited Aliyev to Kazakhstan for an official visit at the ECO meeting held in Ashgabat on 13-14 May 1997. Subsequently, Aliyev paid an official visit to Kazakhstan on 10-11 June 1997. During the visit, a bilateral meeting was held between Aliyev and Nazarbayev and the future perspective of the relations was discussed (Heydar Aliyev Heritage, 2010).

Within the scope of the visit, several important agreements were signed between Azerbaijan and Kazakhstan. The announcement of the declaration on the further development and deepening of cooperation between the parties had the characteristic of determining the future direction of the relations. The memorandum that was signed on the transport of oil resources to international markets was especially important. Agreements of visa-free travel, a free trade agreement, and legal assistance on humanitarian issues were also signed between the two countries (Heydar Aliyev Heritage, 2010). 
The bilateral relations between Azerbaijan and Kazakhstan have reached a new strategic dimension during the Presidency of Ilham Aliyev. During this period, the relations between Azerbaijan and Kazakhstan developed in the format of cooperation both in bilateral and international organizations. President Ilham Aliyev made his first official visit to Kazakhstan on March 1, 2004.

Amicable relations between the two countries were strengthened by the "Declaration of amicable relations and strategic partnership between the Republic of Azerbaijan and the Republic of Kazakhstan" signed on March 1, 2004, in Astana (now Nur-Sultan) (Republic of Azerbaijan Ministy of Foreign Affairs, 2021). The "Agreement on strategic partnership and alliance relations between the Republic of Azerbaijan and the Republic of Kazakhstan" signed in Baku on 24 May 2005 was an indication of the strategic level of bilateral relations (Republic of Azerbaijan Ministy of Foreign Affairs, 2021).

During the working visit of President Ilham Aliyev to Kazakhstan in June 2006, two important documents were signed on the transport of Kazakh oil to European markets by the Baku-TbilisiCeyhan (BTC) oil pipeline through the Caspian Sea and Azerbaijan lands (Huseynov, 2017: 141).

The official visit of President Ilham Aliyev to Kazakhstan in August 2007 had an important place in terms of the development of relations. During the visit, priority areas of bilateral relations were discussed with President Nazarbayev. Nazarbayev stated that "they are interested in transit freight transportation that will reach Europe from Azerbaijani lands". Nazarbayev also expressed his support for "transportation of Azerbaijani goods to Central Asia and China via Kazakhstan" (Ismayilova, 2011: 199).

President Ilham Aliyev's next visit to Kazakhstan was performed on May 5, 2008, where he attended the meeting held for the $10^{\text {th }}$ anniversary of the establishment of Astana (Heydar Aliyev Heritage,2010). Azerbaijan's consulate in Aktau commenced activities on September 6, 2008 (Republic of Azerbaijan Ministy of Foreign Affairs, 2021).

In 2009, mutual visits were made between the two countries at the level of Heads of State. An unofficial summit of the leaders of Azerbaijan, Kazakhstan, the Russian Federation, and Turkmenistan was held on September 11, 2009, in Aktau, Kazakhstan. Nazarbayev stated at the summit that "various bilateral and multilateral cooperation issues should be addressed" (Akorda, 2009).

President Nazarbayev made an official visit to Azerbaijan on October 2, 2009. Within the scope of the visit, the "Memorandum on the joint use of oil and gas infrastructure facilities in the context of the development of the hydrocarbon fields of the Republic of Kazakhstan by the State Oil Company of the Republic of Azerbaijan" was signed (Heydar Aliyev Heritage,2010). The two leaders met again during the Turkic Council Summit held in Almaty on 20 October 2011. In his meeting with Aliyev, Nazarbayev emphasized that mutual visits between the two countries became a tradition and that relations reached a high level (Akorda,2011).

Nazarbayev, who visited Baku in 2017, stated that this visit should be a spark for the further development of relations within the framework of a new format. Nazarbayev emphasized the damage caused by the global crisis environment to national economies and spoke about the importance of diversifying economic relations and integrating innovative technologies into the economy. (Kapital Kazaxstan, 2017). At the ceremony held in Baku on April 3, 2017, President Nazarbayev was awarded the "Heydar Aliyev Order", the highest state order of Azerbaijan, for his special services in the development of friendly relations and cooperation between the two countries (The Library of the First President of the Republic of Kazakhstan-Elbassy, 2020).

In the Presidential election held on 9 June 2019, Kasym Jomart Tokayev was elected as the second President of Kazakhstan. Relations with Azerbaijan, which Elbasy Nazarbayev attributed special 
importance to, followed a positive course during the Tokayev period as well. Serjan Abdikerimov, Kazakhstan's Ambassador to Azerbaijan stated that "the strategic cooperation built by Heydar Aliyev and Nursultan Nazarbayev was successfully continued by President Tokayev" (Abdikerimov, 2019). Meeting with Ilham Aliyev at the Munich Security Conference on February 14, 2020, Tokayev said that "Azerbaijan is the key partner of Kazakhstan in the South Caucasus and Caspian region" (Interfax-Azerbaijan, 2020).

\subsection{Cooperation in Determining the Legal Status of the Caspian}

With its strategic and geopolitical position, the Caspian region deeply affects the political, economic, and socio-political developments and trends in the Eurasian geography. With the dissolution of the USSR, this region where Azerbaijan, Kazakhstan, Turkmenistan, Russia, and Iran are riparian states has started to play an important role in global politics due to its convenient geographical location, transportation potential and natural resources.

Considered to be the largest lake in the world, named a sea in the historical process, and having various natural resources, the Caspian was "used without dispute between Tsarist Russia / USSR and Iran" (Abdullayev, 1999: 255). The total length of the Caspian Sea's coastline is 7,010 km. "Kazakhstan has a coastline of $2.340 \mathrm{~km}$, Russia $1.930 \mathrm{~km}$, Turkmenistan $1.200 \mathrm{~km}$, Azerbaijan $800 \mathrm{~km}$, and Iran $740 \mathrm{~km}$ " (Amirbek, 2015: 24). The international legal status of the Caspian has been addressed many times since 1992 in the bilateral and multilateral views of the riparian countries. A common attitude towards the status of the Caspian as a sea or a lake has not been established for a long time (Aliyev, 2009). Against the middle line principle advocated by Azerbaijan, Kazakhstan, and Russia, Turkmenistan had a different attitude towards the method, although it adopted the principle of "sharing the sea". Iran, on the other hand, was against both sharing principles and reiterated its view that Iran should have at least $20 \%$ of the Caspian" (Terzioğlu, 2008: 41).

Since the mid-1990s, a consensus has been achieved between Azerbaijan and Kazakhstan on the delimitation of the Caspian Sea. Azerbaijan argued that the Caspian "be divided into national sectors according to the principle of midlines among the five coastal states so that each coastal state has sovereign rights just like its own land area" (Abdullayev, 1999: 269). Azerbaijan and Kazakhstan have taken a common attitude in sharing according to the principle of national sectors (Aliyev,2009). In this context, it can be said that there is similarity in the views advocated by Azerbaijan and Kazakhstan. That is because it is important for Azerbaijan to determine its own area of sovereignty in terms of a final division rather than evaluating the Caspian as a sea or a lake" (Abdullayev, 1999: 279).

Heydar Aliyev stated in the interview he gave within the scope of his visit to France in 1997 that, "the attitudes of Azerbaijan and Kazakhstan were the same" (Aliyev, 2009: 193). In 1998, Russia and Kazakhstan signed a series of agreements regarding the status of the Caspian. Azerbaijan accepted that the agreements signed between Russia and Kazakhstan could form the basis for the solution of the legal status of the Caspian and lay the groundwork for the preparation of the Convention on the Legal Status of the Caspian. Additionally, under the influence of the increasing speed of cooperation between Kazakhstan and Russia, Azerbaijan and Russia made a joint statement on the principles of cooperation in the Caspian on January 9, 2001 (Ayulbayev, 2009: 22).

At the CIS Summit held in Moscow on November 29, 2001, the leaders of Azerbaijan and Kazakhstan signed an agreement on the status of the Caspian. In the agreement made between Azerbaijan, Kazakhstan and Russia in May 2003, three riparian countries found a middle ground and took the same attitude in solving the Caspian problem (Ayulbayev, 2009: 23). 
After 22 years of long negotiations, the five riparian countries managed to fully agree on all provisions regarding the legal status of the Caspian Sea (Memmedov, 2019: 176). The Presidents of Azerbaijan, Kazakhstan, Turkmenistan, Russia, and Iran signed the agreement that determines the legal status of the Caspian at the $5^{\text {th }}$ Summit of the Caspian Littoral Countries, held in Aktau on 12 August 2018 (Akorda, 2018).

\subsection{Kazakhstan's Attitude towards the Nagorno-Karabakh Conflict}

Gaining international and regional support for a solution for the Nagorno-Karabakh conflict was the main direction of post-independence Azerbaijani foreign policy. In this context, Azerbaijani diplomacy was making an intense effort. The region was occupied by Armenia between 19881993 and more than one million Azerbaijanis had to leave their historical lands. In 1994, a ceasefire agreement was signed between Azerbaijan and Armenia, and the solution of the problem started to be discussed before the Minsk Group of the Organization for Security and Cooperation in Europe (OSCE). The activities of the Minsk Group, which has been co-chaired by the United States of America (USA), Russia and France since 1994, were inconclusive. Thus, with the military operation that started on September 27, 2020, and lasted for 44 days, which was in line with international legal principles, the Azerbaijani Armed Forces saved the occupied territories. Azerbaijan's victory in Nagorno-Karabakh deeply affected regional geopolitical dynamics.

Kazakhstan has repeatedly declared that it favors the solution to the Nagorno-Karabakh problem through negotiations. Since it gained independence, Kazakhstan has consistently opposed any signs of escalation of the conflict (Yergaliyev, 2020). Besides, it has repeatedly affirmed its commitment to the inviolability of the administrative borders of the republics during the dissolution of the former USSR. Kazakhstan has followed policies that oppose all kinds of separatism as a matter of principle. This point indicates that Kazakhstan supports the territorial integrity of Azerbaijan. Kazakhstan blocked Armenia's admission to the Eurasian Economic Union (EAEU) because it has unsolved problems with Azerbaijan. For this reason, there have been constant diplomatic tensions between Yerevan and Nur-Sultan (Satpayev, 2020).

After the dissolution of the USSR, Kazakhstan had good relations with both Azerbaijan and Armenia. In this context, Kazakhstan was developing amicable relations with these two CIS countries (Galiyev, 2012: 38). Therefore, Kazakhstan was looking at the issue from the perspective of the CIS and the near environment. With this position, Kazakhstan had the potential to act as a mediator in the solution of the problem. For example, in 2016, Nazarbayev made a phone call with both Aliyev and Sargsyan to eliminate the ongoing tension on the Azerbaijan-Armenia border (Kapital Kazaxistan, 2016). Kazakhstan offered Azerbaijan and Armenia a dialogue platform for peace talks during the OSCE Chairpersonship in 2010. This mediation offer was also important in the context of increasing the international prestige of Kazakhstan (Galiyev, 2012: 39). Subsequently, the Foreign Ministers of Azerbaijan and Armenia met in Astana on 17 July 2010. The "Astana Declaration" on the solution of the problem was announced at the $7^{\text {th }}$ Summit of OSCE held in Astana on 1-2 December 2010 (Republic of Azerbaijan Ministy of Foreign Affairs, 2021). The declaration emphasized the peaceful solution of the problem and referred to previous talks. Speaking at the Astana Summit, President Aliyev emphasized that Nagorno-Karabakh were historical Azerbaijani lands and was occupied by Armenia. Aliyev underlined that Armenia did not comply with the principles of international law and violated the ceasefire several times (OSCE Summit, 2010).

When long-lasting negotiations yielded no results, the process of liberation of the occupied territories started with the operation launched by the Azerbaijani Armed Forces on September 27, 2020. Armenia wanted to benefit from the capacity of the Collective Security Treaty Organization (CSTO), of which it is a member, within the framework of its plans. During the 2016 crisis between Turkey and Russia, Armenia's CSTO representative made a statement that the members of the 
organization completely supported Moscow in case of conflict with Ankara. However, member countries such as Kazakhstan, Belarus and Kyrgyzstan protested this statement and reminded that the Armenian representative was not authorized to make such statements on behalf of the organization (Satpayev, 2020).

Armenia could not obtain the support of the CSTO in the war in Nagorno-Karabakh due to the internationally recognized territories of Azerbaijan were occupied and regional conflicts are not included in the CSTO rules (Kurayev, 2020). Therefore, Kazakhstan and other CSTO member countries were prioritizing the de-regionalization of the issue. Thus, Kazakhstan acting within the framework of international legal principles, did not allow CSTO to be used as a part of Armenia's occupying policies.

On November 9, 2020, with the mediation of Russia, the Presidents of Azerbaijan and Armenia signed a ceasefire. The text announced on 10 November 2020, that a new geopolitical reality in the South Caucasus was created. Thus, the Second Karabakh War, which lasted for 44 days and concluded with the victory of Azerbaijan was ended. Azerbaijan liberated Karabakh from occupation and ensured its territorial integrity.

The Ministry of Foreign Affairs of Kazakhstan stated that it supported and appreciated the ceasefire decision (Kostanai News, 2020). And drew attention to the constructive role of Russia in the realization of this agreement and its peacekeeping efforts towards the practical implementation of the agreement (Tass News Agency, 2020). On November 12, 2020, local Kazakhs also participated in the victory celebrations organized by Azerbaijan's diaspora representatives in the city of Aktobe, Kazakhstan. Azerbaijani and Kazakhstani flags were waved side-by-side during the celebrations in Aktobe (Trend News Agency, 2020). Kazakhstan President Tokayev described the agreement as historic in the video conference of the CSTO Security Council (Ria Novosty, 2020).

\subsection{The Effect of the Azerbaijani Diaspora in Kazakhstan on the Development of Political Relations}

The emergence of Azerbaijanis in Kazakhstan is associated with the forced settlement of peoples in the war and pre-war years. The deportation of Azerbaijanis to Kazakhstan took place in three stages. The first stage of the deportation of Azerbaijanis to Kazakhstan was carried out in the late 1930s with the forced expulsion of the oppressed peoples of the Caucasus from their homeland. The second stage took place between the years 1944-1950 and the third stage took place between the 1960s to the 1980s. The Azerbaijanis settled in the new copper industrial areas in Kazakhstan (Assambleya Naroda Kazaxstana, 2021).

With the mass collectivization that started in the USSR in the 1930s, many propertyless people emerged in Azerbaijan and these people settled in Kazakhstan as displaced persons. In 1932, approximately 600 Azerbaijani families who settled in the Aral Sea Islands were transferred to Aralsk city of the Kyzylorda region of Kazakhstan. Many of these families, who were not used to severe frosts, lost their lives after the first winter. Of these families, a total of 200 families survived and they were transferred to Kyrgyzstan (Kozgambayeva, 2017). 50 thousand Azerbaijanis were exiled to Kazakhstan due to Soviet political pressures that started in Azerbaijan in 1937. With hundreds of families settling in Kazakhstan, these lands have become the eternal homeland for Azerbaijanis (Kozgambayeva, 2017). In 1944, various peoples, including Azerbaijanis, were exiled from Soviet Georgia to Kazakhstan.

Azerbaijanis later continued to live in Kazakhstan, after gaining freedom of movement. Undoubtedly, the friendly attitude of the Kazakh people was decisive in this (Kozgambayeva, 2017). Today, Azerbaijanis predominantly live in Shymkent, Jambul, Almaty, and Kyzylorda. Azerbaijanis living in the south of Kazakhstan are mostly engaged in agriculture. Azerbaijani 
societies have been established in all regions and major cities of Kazakhstan. The societies of "Gobustan" in Almaty region, "Azeri" in Jambul, "Vatan" in Pavlodar, "Haydar" in Kostanay, and "Dostluk" in Mangystau can be given as examples (Kozgambayeva, 2017). The "Turan" cultural center, one of the first Azerbaijani communities in Kazakhstan, was established in 1977 (Djafarova, 2013: 71). The "Caspian National-Cultural Center" of Azerbaijanis started its activities in 1999 (Kozgambayeva, 2017).

All kinds of conditions were created for the preservation of the culture, language, and traditions of all peoples living in Kazakhstan after independence. Kazakhstan is a positive example for many post-Soviet countries in this regard. There are schools teaching in Azerbaijani in the cities of Astana, Almaty, and Taldykurgan (Djafarova, 2013: 73). The Union of Cultural Centers of Kazakhstan Azerbaijanis operates in Astana. This union brings together 12 diaspora organizations. The total number of Azerbaijani diaspora organizations in Kazakhstan is 37 (The State Committee on Work with Diaspora of the Republic of Azerbaijan, 2021). The $1^{\text {st }}$ Forum of the Diaspora Organizations of Turkic Speaking Countries was held in Baku on June 21, 2013. The Azerbaijan diaspora in Kazakhstan actively participated in the forum (Djafarova, 2013: 74).

The Azerbaijan diaspora contributes greatly to the development of friendship between peoples. Representatives of the Azerbaijani diaspora include entrepreneurs, engineers, politicians, scientists, education, culture, and sportspeople who contribute to the economic, cultural, and political development of Kazakhstan (Kozgambayeva, 2017). In recent years, the diaspora representatives have started to play a more active role in Kazakhstan's political life. From the diaspora representatives, five oblast (province) deputies, three city deputies and the mayor of Chu were elected (Ceferova, 2019: 99). The Azerbaijan diaspora also ensures the development of relations between the regions of Kazakhstan and Azerbaijan. For example, the diaspora acts as a locomotive in the development of cooperation between the Mangystau region and Azerbaijan, and thus direct flights have started between Aktau and Baku (Velizade, 2019).

\section{Cooperation within the Scope of Regional Energy and Transportation Projects}

After independence, Azerbaijan and Kazakhstan developed cooperation mechanisms at various levels, especially in the fields of regional energy and transportation. Transport and energy fields are priority areas in cooperation between the two countries. Azerbaijan and Kazakhstan successfully implemented the principle of oil exports and diversification of oil supply routes (Djangabayeva, 2009: 27). Efficient regional cooperation was realized within the scope of the BTC oil pipeline, the Baku-Tbilisi-Erzurum natural gas project, and the Baku-Tbilisi-Kars railway project (Muhamedjanov, 2009: 7). In this context, the energy component has determined the direction of economic relations.

The oil sector is the foundation of the economies of Azerbaijan and Kazakhstan, and is developing dynamically in both countries. This sector provides a significant part of the national gross product, budget, and foreign currency revenues of Azerbaijan and Kazakhstan (Nuriyev, 2009: 11). In this context, during the years of independence, the oil and gas sectors in both countries have developed significantly. Kazakhstan sees Azerbaijan as its main partner and sister country in the Caucasus region in the implementation of projects in the fields of energy, transportation, and communication. Developing cooperation and interaction between the western regions of Kazakhstan and the regions of Azerbaijan, and expanding the transportation infrastructure of the Caspian ports are among the main priorities (Djangabayeva, 2009: 27). The "Aktau Production and Logistics Center", which was founded in the special region of Aktau with the investment of Azerbaijan in 2014, plays an important role in the increase of commercial and economic relations between Azerbaijan and Kazakhstan (Republic of Azerbaijan Ministy of Foreign Affairs, 2021). Azerbaijan and Kazakhstan are among the participants of the Transport Corridor EuropeCaucasus-Asia (TRACECA) program. On October 28, 2005, tripartite meetings were held in 
Aktau between transport representatives of Azerbaijan, Kazakhstan and Georgia on the development of transportation in TRACECA. During the meetings, the launch of the container train on the Poti-Baku-Aktau-Almaty route was discussed. At the same time, the railway and transportation tariffs were the subject of the meetings (Djangabayeva, 2009: 32). On December 24, 2005, train services started on the Poti-Baku-Aktau-Almaty route, and train services were planned to be made regularly twice a month. (Day.Az, 2005).

Since 2002, Azerbaijan and Kazakhstan have started to negotiate the BTC project to ensure the transportation of Kazakh oil to world markets. With BTC, it is aimed to transport oil to be produced in the Caspian Region, especially Azerbaijani oil, to Ceyhan, Turkey via Georgia through a safe, economically and environmentally suitable pipeline system and to reach world markets by tankers (Myrzabekova \& Zhaxyglova, 2016: 17). On April 18-19, 2005, negotiations were held between the authorities of Azerbaijan and Kazakhstan on the Aktau-Baku pipeline, which will enable the transportation of Kazakh oil through the BTC, and an agreement was reached on many important issues, including tariffs (Aslanli, 2017: 34). During his visit to Baku on May 25, 2005, Nazarbayev attended the ceremony held in Sangachal regarding the service start of the Azerbaijani section of the BTC pipeline. The Baku Declaration on the Development and Expansion of the East-West Energy Transmission Corridor, in which Kazakhstan also participated, was signed at the ceremony (Heydar Aliyev Heritage, 2010). Consequently, on June 16, 2006, President Nazarbayev signed the agreement regarding Kazakhstan's participation in the BTC pipeline project. The agreement stipulates the provision of tanker transportation of Kazakh oil from Aktau to Baku over the Caspian Sea via the BTC pipeline (Ria Novosty, 2009). During the visit of President Ilham Aliyev to Kazakhstan in 2007, a bilateral cooperation document was signed with Kazakh national oil company KazMunayGas and Azerbaijan State Oil Company (SOCAR) (Kazakistan Business Magazine, 2020) On November 3, 2008, the transportation of Kazakh oil through the BTC pipeline started. On November 14, 2008, an agreement was signed between SOCAR and KazMunayGas on the basic principles of the realization of the Trans Caspian project in Baku. The agreement regulated the conditions and basic principles of the joint realization of the Trans Caspian project, the establishment of a joint company for the project by KazMunayGaz and SOCAR, "the financing of the established company, the determination of tariffs, and the gradual development process of the Trans Caspian system" (Aslanli, 2017: 35).

The Kazakh section of the Caspian Sea contains most of the largest known oil fields of the basin. The Tengis field produces 570,000 barrels of oil per day. The Kashagan field has an estimated 13 billion barrels of oil reserves (Indeo, 2018). Transporting these rich reserves of Kazakhstan to European markets through Azerbaijan is important in terms of economic gains. Azerbaijan has a reliable profile as a transit country. One of the biggest projects in the context of transporting Central Asian oil to European markets is the Trans-Caspian pipeline and transportation project. The oil leg of the project has a more functional nature. The natural gas leg is negotiated in a more cautious and prudent framework in the context of geopolitical reasons.

In 2012, intensive negotiations were held on the fate of the Trans-Caspian oil pipeline. However, the unresolved legal status of the Caspian Sea and the disagreement between countries regarding the financing of the project prevented the project from being implemented (Huseynov, 2017: 150). In 2016, the Minister of Energy of Azerbaijan Natig Aliyev announced that they planned to lay the Trans-Caspian oil pipeline from Kazakhstan to Azerbaijan with an annual capacity of 56 million tons (Neftgaz.ru, 2016). With the project, Kazakh oil would be exported to world markets, especially from the Kashagan field, through the BTC pipeline and other oil transportation systems (Nicklin, 2016).

After the agreement on the resolution of the legal status of the Caspian Sea in 2018, a suitable geopolitical ground was formed for the realization of the project in question. The signing of the 
agreement on the legal status of the Caspian Sea will also allow the growth of foreign investment in all Caspian countries. The functionality of Kazakhstan's Aktau, Bautino and Kuryk ports will increase (Ongarova, 2018: 8). Azerbaijani President Ilham Aliyev stated in his meeting with German Chancellor Angela Merkel on August 26, 2018, that "they would be very interested in the decision to export gas from the east of the Caspian to world markets via Azerbaijan, but this decision should be made by the other party" (Trend News Agency, 2018). Kazakhstan is "more cautious about the Trans-Caspian natural gas cooperation and steadily tries to develop the TransCaspian oil cooperation with Azerbaijan" (Aslanli, 2017: 44).

The leading transportation project that brings Azerbaijan and Kazakhstan together is the East-West Middle Corridor Initiative of Turkey. The Middle Corridor Initiative, which foresees the revitalization of the Silk Road, creates a natural synergy with China's Belt and Road Initiative, which aims to improve the connectivity between East and West (Republic of Turkey Ministy of Foreign Affairs, 2021). The Middle East-West Corridor initiative of Turkey is technically "based on the more functional use of the existing road and rail routes stretching from China to Turkey. One of the steps taken in this context is the use of the Nomad Express, which starts from the city of Shihezi in the Xinjiang Uyghur Autonomous Region of China and reaches Aktau Port on the Mangshlak Peninsula of Kazakhstan" (Toprak, 2020: 24). Starting from Turkey, extending to the Caucasus region, from here to Central Asia and China, crossing the Caspian Sea, Turkmenistan and Kazakhstan, the East-West Middle Corridor constitutes one of the most significant components of the revitalization of the historic Silk Road project (Republic of Turkey Ministy of Foreign Affairs, 2021).

On 7 November 2013, an agreement titled "Establishment of the Coordination Committee for the Development of the Trans-Caspian International Transport Line" was signed between Kazakhstan, Azerbaijan and Georgia. Later, within the framework of the agreement to which China is a party, the first test drive on the Middle Corridor was carried out on 28 July 2015, and the container train (The Nomad Express) departing from Western China successfully reached Baku via Aktau Port 6 days later. With the Baku-Tbilisi-Kars (BTK) Railway going into operation in 2017, an important part of the Middle Corridor was completed (Republic of Turkey Ministy of Foreign Affairs, 2021). The first train set out on the BTK railway line on October 30, 2017. Turkey's President Recep Tayyip Erdogan, Azerbaijani President Ilham Aliyev, Prime Minister of Kazakhstan Bakitcan Sagintayev, Prime Minister of Uzbekistan Abdulla Aripov, and the Prime Minister of Georgia Giorgi Kvirikashvili participated in the opening ceremony of the BTK railway line. The grain brought from Azerbaijan to Kazakhstan in the first voyage on the line was transported from the Elet station to Turkey's Mersin port (Dünya, 2017).

\section{Conclusion}

After independence, the political, economic, and cultural relations between Azerbaijan and Kazakhstan gradually strengthened. The multidimensional cooperation between the two countries enables the solution of problems and the establishment of stability in the Caspian basin and Central Asia. In this context, the dialogue, friendship and partnership between Azerbaijan and Kazakhstan set an example for the cooperation and interaction between the countries of the Turkic world.

Undoubtedly, Azerbaijan's national leader Heydar Aliyev and Kazakhstan's founding President, Nursultan Nazarbayev, have played a decisive role in the development of bilateral relations. The constructive dialogue between the two leaders has enabled bilateral relations to rise to a strategic dimension. The tradition of mutual and fruitful visits in bilateral political relations was maintained during the period of President Ilham Aliyev. In this context, friendly relations based on mutual trust exist between Kasym Jomart Tokayev, who was elected President of Kazakhstan in 2019, and Ilham Aliyev. 
The energy and transportation fields have served as the locomotive of Azerbaijan-Kazakhstan economic relations. The constructive and multilateral cooperation in these two priority areas has played an important role in ensuring regional stability and prosperity. Due to their key roles in the BTC pipeline project, the Trans-Caspian oil pipeline, and the Middle Corridor transportation project, the synergy between the two countries is very important for global and regional economic prosperity. The economic relations between the two countries have reached a new level within the framework of the investments made by the Azerbaijani capital in Kazakhstan in recent years.

No doubt, the dynamics shaping the relations between Azerbaijan and Kazakhstan are related to the new de facto regional realities. A suitable ground was formed for the development of regional economic activities following the historical victory of Azerbaijan in Karabakh. This favorable ground further increased the cooperation capacity of these two important countries. In this respect, it must be underlined that Azerbaijan was elevated to a decisive position in the economic and transportation policies of Kazakhstan and other Central Asian Republics. This decisive position will be further reinforced with the opening of the strategically important Zangezur Corridor. In this way, a regional cooperation area that will have high potential will be formed on the Central Asia-Caspian-South Caucasus-Turkey line. This novel cooperation area will allow for increased regional prosperity and reinforced economic interaction among countries. These new regional realities will also carry the Azerbaijan-Kazakhstan relations to a new strategic level, and economic perspectives will come to the forefront.

Moreover, cultural relations between Azerbaijan and Kazakhstan are constantly improving both bilaterally and through international platforms such as the Turkic Council and TURKSOY. A common history, traditions, and cultural ties prepare the ground for the further development of the relations. In this context, cooperation and joint activity opportunities between the two countries in the cultural field are quite high. Understandably, cultural relations have intensified since the two countries gained their independence. "Az-ya", the famous book of Oljas Suleymanov, one of the most important poets of the $20^{\text {th }}$ century, who voiced the rights of Azerbaijanis to the world during the difficult years of Soviet Azerbaijan, started to be published in Azerbaijan in the 1980s. The Azerbaijan-Kazakhstan Friendship Society was established in Baku in 1993 to develop cultural ties. This society brings together writers, folk artists, painters, film directors, and the business circles of the two countries. The community plays an important role in the development of Azerbaijan-Kazakhstan relations.

In conclusion, it is possible to say that the political and regional relations between Azerbaijan and Kazakhstan, which are part of a common history and culture, have a great perspective. The strategic partnership existing between the two countries also significantly affects regional dynamics.

\section{References}

Abdikerimov, S. (2019). Tokayev Bakı ile elaqelerin inkişafına mühüm ehemiyyet verir. Retrieved from .https://azvision.az/news/196427/-tokayev-baki-ile-elaqelerin-inkisafina-muhunehemiyyet-verir--sefir---.html

Abdullayev, C. (1999). Uluslararası hukuk çerçevesinde Hazar'ın statüsü ve doğal kaynaklarının işletilmesi sorunu. Ankara Üniversitesi Hukuk Fakültesi Dergisi, 1 (4), 255-290.

Ahmedov, A. (2013). Azerbaydjan-Kazaxstan: iz İstoriyi Vozniknoveniya Politicheskiy Otnosheniy (90-e gg XX veka). Vestnik KazNU, Almaty.

Akorda Ofitsyalniy Sayt Prezidenta Respubliki Kazaxstan. (2009). V Aktau sostayalsya Neformalniy Sammit Azerbaydjana, Kazaxstana, Rossii i Turkmenistana. Retrieved from http://www.akorda.kz/ru/events/v-aktau-sostoyalsya-neformalnyi-sammit-azerbaidzhanakazahstana-rossii-i-turkmenistana 
Akorda Ofitsyalniy Sayt Prezidenta Respubliki Kazaxstan. (2011). Vstrecha Nursultana $\begin{array}{lllll}\text { Nazarbayeva } & \mathrm{s} & \text { İlxamom } & \text { Aliyevym. } & \text { Retrieved }\end{array}$ https://www.akorda.kz/ru/special/events/glava-gosudarstva-nursultan-nazarbaevvstretilsya-s-prezidentom-respubliki-azerbaidzhan-ilhamom-alievym-kotoryi-pribyl-vkazahstan-s-oficial

Akorda Ofitsyalniy Sayt Prezidenta Respubliki Kazaxstan. (2018). Komnyuke Pyatogo Kaspiyskogo Sammita. $\quad$ Retrieved from https://www.akorda.kz/ru/events/astana_kazakhstan/astana_other_events/kommyunikepyatogo-kaspiiskogo-sammita

Aliyev, A. (2009). Sahilyanı Dövletlerin Xezer siyaseti. Tarix ve Onun Problemleri, (1), 192-201.

Amirbek, A. (2015). Soğuk savaş sonrası Hazar'ın statüsü ve sınırlandırma sorunu: Kıyıdaş Devletler'in yaklaşımları açısından analizi. Karadeniz Araştırmaları, (46), 23-48.

Aslanli, A. (2017), Trans Hazar Enerji İş Birliğinin Türk Cumhuriyetleri açısından önemi, Bilig, Türk Dünyast Sosyal Bilimler Dergisi, (89), 27-51.

Assambleya Naroda Kazaxstana. (2021). Etnosi Kazaxstana. Retrieved from https://assembly.kz/ru/ethnos/ru/azerbaydzhantsy/

Ayulbayev, B. (2009). "Pozitsiya Kazaxstana i Azerbaydjana Vnesli Bolshoy Vklad v Opredeleniya Pravovogo Statusa Kaspiyskogo Morya". Retrieved from https://online.zakon.kz/Document/?doc_id=30361746\#pos=3;-80

Azerbaycan Respublikasının Qazaxistan Respublikasındaki Sefirliyi. Azerbaycan ile Qazaxstan arasında ticaret dövriyyesi süretle artır. Retrieved from https://nursultan.mfa.gov.az/az/news/3193/azerbaycan-ile-qazaxistan-arasinda-ticaretdovriyyesi-suretle-artir

Ceferova, R. (2019). Merkezi Asiya Respublikalarında Azerbaycan Diasporunun teşekkülü ve fealiyyet tarixi. Bak1: Turxan.

Day.Az. (2005). İz Poti otpravlen perviy konteynerniy poezd po marshrutu Poti-Baku-AktauAlmaty. Retrieved from https://news.day.az/georgia/37834.html

Djafarova, R. (2013). Deyatelnosty Azerbaydjanskoy Diaspori v Respublike Kazaxstan v Postsovetskiy Period. Jurnal Sovremennaya Nauchnaya Mysli (3), 68-74.

Djangabayeva, K. (2009). "Perspektivi Torgovo-Ekonomicheskogo Sotrudnichestvo Kazaxstana i Azerbaydjana". Kazakhstan $i$ Azerbaydjan:Perspektivi Sotrudnichestva $i$ Vzaimodeystviya, Materyali Kazaxtansko-Azerbaydjanskogo Kruglogo Stola. Almaty.

Dünya Gazetesi. (2017). Bakü-Tiflis-Kars demiryolu'nda ilk tren yola çıktı. Retrieved from https://www.dunya.com/ekonomi/baku-tiflis-kars-demiryolunda-ilk-tren-yola-ciktihaberi-388824

Galiyev, A. (2012). Kazaxstan kak Peregovornaya Ploshadka po Uregulirovaniyu ArmyanoAzerbaydjanskogo Konflikta Vokrug Nagornogo Karabaxa. Kavkaz\&Globalizatsiya, (3), 33-39.

Heydar Aliyev Heritage International Online Library. Azerbaycan-Qazaxstan münasibetleri. Retrieved from https://ib.aliyevheritage.org/az/549420.html

Huseynov, R. (2017). Azerbaijan-Kazakhstan Relations: Current Situation and Prospects. Retrieved from http://przeglad.amu.edu.pl/wp-content/uploads/2017/10/pp-2017-3-11.pdf 
Huseynova, R. (2014). “Azerbaycan-Qazaxstan Münasibetleri (1993-2003-cü iller)”. Retrieved from http://az.strategiya.az/news.php?id=17289

Indeo, F. (2018). Settling the Caspian Issue and Realizing the Trans-Caspian Energy Corridor. Retrieved from https://thediplomat.com/2018/07/settling-the-caspian-issue-and-realizingthe-trans-caspian-energy-corridor/

Interfax-Azerbaijan. (2020). Konventsiya o statuse Kaspiya zalojila fundament dlya krupnomasshtabnogo sotrudnichestva $\mathrm{V}$ regione- Tokayev. Retrieved from https://interfax.az/view/792525

Ismayilova, S. (2011). Nezavisimiy Azerbaydjan i Vzaimootnosheniya s Tyurkskimi Gosudarstvami. Tarix ve Onun Problemleri, (3), 197-204.

Kapital Kazaxistan. (2016). Prezident prizval k deskalatsyii situatsyii v Nagornom Karabaxe. Retrieved from https://kapital.kz/gosudarstvo/49278/prezident-prizval-k-de-eskalatsiisituatsii-v-nagornom-karabakhe.html

Kapital Kazaxistan. (2017). Nursultan Nazarbayev Vstretilsya s İlxamom Aliyevym. Retrieved from https://kapital.kz/gosudarstvo/58705/nursultan-nazarbayev-vstretilsya-s-il-khamomaliyevym.html

Kazakhstan Business Magazin. (2020). Esho odin shag na puty k realizatsyi Transkaspiyskogo Proyekta. Retrieved from http://www.investkz.com/articles/1708.html

Kostanai News (2020). MID Kazaxstana sdelal zayavleniye po situatsiyu v Karabaxe. Retrieved from https://kstnews.kz/news/kazakhstan/item-63103

Kozgambayeva, G.(2017). Deportatsiya Azerbaydjantsev v Kazaxstan. Vestnik KazNU, (1) Retrieved from https://articlekz.com/article/18117

Kurayev, I. (2020). Vopros Nagorno-Karabaxskogo konflikta ne vihodit v obyazannosti ODKB. Trend News Agency, Retrieved from https://www.trend.az/azerbaijan/karabakh/3317353.html

Memmedov, R. (2019). Mejdunarodno-Pravovoye Soderjaniya i Znacheniya Konventsyii o Pravovom Statuse Kaspiyskogo Morya ot 12 Avgusta 2018 goda, Jurnal Problemi Postsovetskogo Prostranstva, (3), 175-194.

Muhamedjanov, B. (2009). "Privetstvennoye Slovo". Kazakhstan i Azerbaydjan:Perspektivi Sotrudnichestva i Vzaimodeystviya, Materyali Kazaxtansko-Azerbaydjanskogo Kruglogo Stola. Almaty.

Myrzabekova, M \& Zhaxyglova, G. (2016). Boru hattı lojistiği: Kazakistan-Türkiye işbirliği imkânların değerlendirmesi. The International New Issues in Social Sciences (3), 7-23.

Neftgaz.Ru. (2016). Azerbaijan and Kazakhstan are Planning to Lay New Eksene-Kuryk-Baku Oil Pipeline. Retrieved from https://neftegazru.com/news/oil/409593-azerbaijan-andkazakhstan-are-planning-to-lay-new-eskene-kuryk-baku-oil-pipeline/

Nicklin, A. (2016). Kazakhstan and Azerbaijan to Lay New Oil Pipeline. Retrieved from https://www.worldpipelines.com/contracts-and-tenders/07102016/kazakhstan-andazerbaijan-to-lay-new-oil-pipeline/

Nuriyev, E. (2009). Kazaxstan i Azerbaydjan: Perspektivi Sotrudnichestva i Vzaimodeystviya. Kazakhstan i Azerbaydjan:Perspektivi Sotrudnichestva $i$ Vzaimodeystviya, Materyali Kazaxtansko-Azerbaydjanskogo Kruglogo Stola. Almaty: 9-18. 
Ongarova, Y. (2018). Kazakistan'ın çok yönlü enerji politikası ve Hazar Denizi, Alınteri Sosyal Bilimler Dergisi (ASOBID), (3), 1-21.

OSCE Summit in Astana. (2010). Astana Sammiti. Retrieved from http://anl.az/el/emb/QARABAQ/beynelxalq-senedler/atet(astana-sammiti).pdf

Republic of Azerbaijan Ministy of Foreign Affairs. İkiterefli Münasibetler. Retrieved from https://www.mfa.gov.az/az/content/215/qazaxistan

Republic of Azerbaijan Ministy of Foreign Affairs. Dvuxstoronniye otnosheniya. Generalnoye Konsulstvo Azerbaydjanskoy Respubliki $\mathrm{v}$ gorode Aktau. Retrieved from .https://aktau.mfa.gov.az/ru/content/3/dvustoronnie-otnosheniya

Republic of Azerbaijan Ministy of Foreign Affairs. Münaqişenin helli prosesi. Retrieved from https://www.mfa.gov.az/az/content/111/munaqisenin-helli-prosesi

Republic of Azerbaijan Ministy of Foreign Affairs. Qazaxstan. Retrieved from https://mfa.gov.az/az/content/215/qazaxistan

Republic of Turkey Ministy of Foreign Affairs. “Türkiye'nin çok taraflı ulaştırma politikası. Retrieved from http://www.mfa.gov.tr/turkiye_nin-cok-tarafli-ulastirma-politikasi.tr.mfa

Ria Novosty. (2009). Neftprovod Baku-Tbilisi-Djeyxan im. Geydara Aliyeva. Ria Novosty, Retrieved from https://ria.ru/20090417/168381928.html

Ria Novosty. (2020). Prezident Kazaxstana nazval soglasheniyu po Karabaxu istoricheskim. Retrieved from https://ria.ru/20201202/karabakh-1587329652.html

Satpayev, D. (2020). My ne mojhem podderjat Armeniyu, ne lishivshis svyazey s Azerbaydjanom: kak skajetsa konflikt Nagornom Karabaxe na Kazaxstane. Retrieved from https://www.caravan.kz/news/my-ne-smozhem-podderzhat-armeniyu-ne-lishivshissvyazejj-s-azerbajjdzhanom-kak-skazhetsya-konflikt-v-nagornom-karabakhe-nakazakhstane-677329/

Sultanov, B. (2009). "Privetstvennoye Slovo". Kazakhstan $i$ Azerbaydjan:Perspektivi Sotrudnichestva i Vzaimodeystviya, Materyali Kazaxtansko-Azerbaydjanskogo Kruglogo Stola. Almaty: 4-5.

Tass News Agency. (2020). MiD Kazaxstana Otmetil Konstriktivnuyu Rol Rossii v Uregulirovaniyi v Nagornom Karabaxe. Retrieved from https://tass.ru/mezhdunarodnayapanorama/9971049

Terzioğlu, S. (2008). Hazar'ın statüsü hakkında kıyıdaş devletlerin hukuksal görüşleri. Orta Asya ve Kafkasya Araştırmaları Dergisi, (5), 26-47.

The Library of the First President of the Republic of Kazakhstan. Visokaya nagrada. Retrieved from https://presidentlibrary.kz/ru/news/vysokaya-nagrada

The State Committee on Work with Diaspora of the Republic of Azerbaijan. Diaspora map. Retrieved from http://diasporamap.com/az/country/119

The State Statistical Committee of the Republic of Azerbaijan. Retrieved from https://www.stat.gov.az/source/trade/

Toprak, N. G. (2020). Orta koridor girişimi bağlamında Türkiye'nin değişen orta asya politikası. Ahi Evran Sosyal Bilimler Enstitüsü Dergisi, (1), 19-32.

Trend News Agency. (2018). Prezident İlham Eliyev: Transxezer kemerinin tikintisi daha çox qazın aahibi üçün maraqlı olmalıdır, tranzit ölkeler burada teşebbüs göstermemelidir. Retrieved from https://az.trend.az/azerbaijan/politics/2944104.html 
Trend News Agency. (2020). Na ulitsah Aktobe Kazaxi i Azerbaydjantsi otmetili pobedu avtoprobegom Karabax-eto Azerbaydjan. Retrieved from https://www.trend.az/life/socium/3333635.html

Velizade, I. (2019). Tsentralnaya Aziya dlya Azerbaydjana-prioritetniy partner. Cabar - Central Asian Bureau for Analytical Reporting: 1-7.

Yergaliyev, G. (2020). Chem grozit Kazaxstanu konflikt mejdu Armeniey i Azerbaydjanom. Retrieved from https://zonakz.net/2020/10/05/chem-grozit-kazaxstanu-konflikt-mezhduarmeniej-i-azerbajdzhanom/ 